\title{
Workplace Violence: A Study of Turkish Workers
}

\author{
Serpil Aytac \\ Veysel Bozkurt \\ Nuran Bayram \\ Selver Yildiz \\ Mustafa Aytac \\ Faculty of Economics and Administrative Sciences, Uludag University, Bursa, Turkey
}

Fusun Sokullu Akinci

Faculty of Law, Istanbul University, İstanbul, Turkey

\section{Nazan Bilgel}

Faculty of Medicine, Uludag University, Bursa, Turkey

This research was conducted to address the experience of workplace violence of Turkish workers from different sectors and to investigate the impact of the exposed violence on their psychological well-being. Data were collected anonymously with printed questionnaires from the volunteer participants and depended on self-reporting. The response rate was 79.0\% (1708/2161). The prevalence of workplace violence was found to be $44.8 \%$. The most common type was verbal violence together with mobbing (bullying). Victims of physical violence were mostly males, whereas females were found to be victims of verbal, psychological and sexual violence. Most cases did not result in legal action and the victims remained silent. Psychological well-being of exposed workers in terms of depression, anxiety and stress seemed to deteriorate. Workplace violence remains a silent epidemic in Turkey. Preventive measures against workplace violence and social support for violated workers do not exist.

$$
\text { workplace violence physical violence psychological violence Turkey }
$$

\section{INTRODUCTION}

Violence has been defined by the World Health Organization (WHO) as the intentional use of physical force or power, threatened or actual, against oneself, another person or against a group or community that either results in or has a high likelihood of resulting in injury, death, psychological harm, maldevelopment or deprivation [1]. Workplace violence is a type of violence which occurs in workplaces and is classified under the community violence subgroup of interpersonal violence [1].

Workplace violence has its origin in a number of factors. Individual factors (gender, age, etc.) may heighten the risk. Environmental factors (poor security, inadequate lightning, night shifts, etc.) can increase the risk of being victimized. Understaffing, excessive workload, inadequate working climate, mistrust and miscommunication and several

This study was supported and funded (project T-2007/41) by the Scientific Research Projects Commission of Uludag University, Bursa, Turkey. The authors would like to thank Scribendi Inc., Canada, for editing the manuscript.

Correspondence and requests for offprints should be sent to Nazan Bilgel, Uludag University, Faculty of Medicine, Department of Family Medicine, Bursa, Turkey 16059. E-mail: <nazan@uludag.edu.tr>. 
other organizational factors may contribute to violence in workplaces [1, 2]. Violence at work can trigger a range of physical and emotional outcomes in victims such as anger, shock, fear, depression, anxiety, stress and sleep disturbances. Furthermore, being victimized at work may result in diminished job satisfaction $[3,4]$.

The true morbidity of violence in workplaces is difficult to estimate. Whereas physical violence at the workplace has always been recognized, the existence of psychological violence has long been underestimated and is now receiving due attention [5]. Surveys have shown that the current figures represent only the tip of the iceberg [5, $6,7]$. Most workplace violence studies in the literature have been conducted in the health care sector and revealed high morbidity. In country case studies, Di Martino reported high rates of psychological assaults ranging from $32.2 \%$ in Bulgaria to $67.0 \%$ in Australia, and the rate of physical violence ranged from 3\% in Lebanon to $17 \%$ in South Africa [5]. In Spain, $11 \%$ of health care workers had been a victim of physical aggression while $64 \%$ had been exposed to threatening behavior, intimidation or insults [7]. A study in Saudi Arabia showed that about $28 \%$ of primary health care workers had been exposed to at least one violent event at their workplace [8]. Studies carried out in the USA, Canada, Australia and New Zealand revealed the importance of this problem and the need for immediate action $[6,9,10]$. The developed world is aware of the problem and tries to solve it by taking the necessary preventive measures or interventions that are based on scientific studies. On the other hand, in the developing world, workplace violence is a neglected phenomenon, and studies investigating this subject are limited.

In Turkey, workplace violence has become an important issue in recent years, and some descriptive studies have been done. Most studies dealt with workplace violence in the health care sector, and the morbidity was found to be high. Studies among workers in hospital emergency services showed that $72 \%$ of the workers had been exposed to violence, and the most common type was psychological violence $[11,12]$. Another study performed in primary health care settings in the western part of Turkey found that $49.5 \%$ of the health care workers had experienced workplace violence, mostly verbal and psychological [13]. Studies also showed that among different types of health care personnel the most victimized were nurses and resident doctors $[14,15,16]$. All these studies in health care settings revealed that the morbidity of the workplace violence in that sector is high, workplace violence is seen mostly as psychological and verbal violence and the prevalence of physical violence is 8.5-19.7\% [11, 12, 13, 14, 15, 16]. Despite the recent studies in the health care sector, the level and type of workplace violence in other work sectors in Turkey remain unclear. We performed this study to obtain some epidemiological data on workplace violence in different work sectors in addition to health care. With this study, we wanted to answer several questions.

- How many workers in different sectors have been exposed to different types of violence in the past 12 months?

- Are there any relationships among the sociodemographic characteristics and being victimized?

- Who were the perpetrators?

- What actions did the victims take?

- What were the consequences of experiencing workplace violence in terms of stress, anxiety, depression and job satisfaction?

\section{MATERIAL AND METHOD}

\subsection{Setting}

This study was carried out in Bursa, Turkey, from November 15, 2007, to December 24, 2008. Workplaces were randomly selected from five different work sectors: industry, service, security, health care and education. For the industry sector, 10 small textile, automotive and food enterprises with 20-30 workers were chosen; for the service sector, two shopping malls each with about 250 workers were selected. For the security, health care and education sectors, participants were selected among government employees working at police stations, hospitals and schools in the 
city; 13 police stations, 7 hospitals and 9 schools were included in the study.

\subsection{Study Approval}

This study was approved by the ethical committee of the university. Furthermore, approval from the Directorate of Security, Directorate of Health and Directorate of Education of the city of Bursa was obtained separately.

\subsection{Participants}

These selected workplaces were visited by the authors on the given dates; printed questionnaires were distributed to the workers who gave their written consent to participate in the study. All of the volunteer participants were informed about the study and asked to fill out the questionnaires without identifying themselves. The questionnaires were distributed and collected in closed envelopes on the same day; the respondents had one hour to fill them out. Those who did not want to participate were excluded from the study. The following numbers of questionnaires were distributed in each sector: industry 352 , service 445 , security 629 , health care 1220 and education 354. Out of the 3000 distributed questionnaires, 2012 were collected (the response ratio was $67.1 \%$ ). Because of a large amount of missing data, 304 of the questionnaires were excluded from the analysis.

\subsection{Study Instruments}

The questionnaire was developed on the basis of the Workplace Violence in the Health Sector project [17] and a comprehensive literature review. There were 34 questions: 12 on sociodemographic data and workplace information, and 24 on workplace violence, types of violence, responses to violence, factors relating to violence, impact of violence, guidelines, training and support from management. For example, to gain workers' opinions on managerial guidelines, training and support, one question asked, "What do you think your manager should do to prevent workplace violence? (You may tick more than one box)".
A list of options based on findings from the literature review followed; the respondents ticked the appropriate ones: training for better communication, training about workplace violence and support for victims, training to overcome stress, establishing policies that give more importance to workers or others. For most questions, respondents were given options but were afforded, with open-ended questions, the opportunity to elaborate further to offer alternative responses.

For this study, violence was defined as any incident in which staff were abused, threatened or assaulted in circumstances related to their work with the result that the staff member was put at risk [1, 17, 18]. Four types of violence were categorized, i.e., physical assault, verbal abuse, bullying and sexual harassment [2, 17, 18]. Physical assault refers to the use of physical force against another person or group that results in physical, sexual or psychological harm. Physical assault can include beating, kicking, slapping, stabbing, shooting, pushing, biting and/or pinching, among others [17]. Verbal abuse refers to the use of words that are personally insulting, such as generally abusive spoken obscenities and foul language, or indicating a lack of respect for the dignity and worth of an individual [18]. Bullying refers to offensive behavior repeated over time through vindictive, cruel or malicious attempts to humiliate or undermine an individual or groups of employees [17, 18]. Sexual harassment refers to any unwanted, unreciprocated and unwelcome behavior of a sexual nature that is offensive to the person involved, and causes that person to feel threatened, humiliated or embarrassed [17, 18].

In addition to the questionnaire, the respondents filled out two forms. One measured their job satisfaction, the other evaluated stress, depression and anxiety. We used Brayfield and Rothe's index of job satisfaction [19] adapted into Turkish by Bilgin [20]. This index consisted of five statements, with responses scored on a 5-point scale from 1 (strongly disagree) to 5 (strongly agree). Higher scores mean high job satisfaction. The reliability of this scale was Cronbach's $\alpha=.76$. 
To measure depression, anxiety and stress, we used Lovibond and Lovibond's DASS-42 scale [21] adapted into Turkish by Uncu, Bayram and Bilgel [22]. This is a 42-item instrument measuring current (within the past week) symptoms of depression, anxiety and stress. Each of the three scales consists of 14 items that are answered on a 0-3 scale where 0 is did not apply to me at all and 3 is applied to me very much or most of the time (the range of possible scores for each scale is $0-42$ ). Scores considered in the normal range are $0-9$ for depression, $0-7$ for anxiety and $0-14$ for stress. Scores above these ranges indicate the degree of problem from mild to extreme. Cronbach's $\alpha$ was .92 for depression, .88 for anxiety and .90 for stress.

\subsection{Data Analysis}

SPSS version 13.0 was used to analyze data. Descriptive statistics were calculated. The $\chi^{2}$ test was used as a test of significance in univariate analysis of the predictors of the outcome variable (exposure to any type of violence in the past year). Binary logistic regression analysis was performed for the possible predictors of exposure to violence. The unit of analysis in the model was the victim, not the violent event. Odds ratios and their confidence intervals were presented.

The consequences of exposure to violence in terms of job satisfaction and depression, anxiety and stress were evaluated with the MannWhitney $U$ test by comparing the mean values of job satisfaction and DASS-42 scores among the exposed and nonexposed workers; $p \leq .05$ was considered statistically significant.

\section{RESULTS}

\subsection{Sociodemographic and Working Characteristics}

Table 1 shows the distribution of study participants according to age, education, marital

TABLE 1. Distribution of Study Participants According to Demographic and Work Characteristics

\begin{tabular}{|c|c|c|c|c|c|c|c|}
\hline \multirow[b]{2}{*}{ Characteristic } & & \multicolumn{2}{|c|}{ Male } & \multicolumn{2}{|c|}{ Female } & \multicolumn{2}{|c|}{ Total } \\
\hline & & $n$ & $\%^{\mathrm{a}}$ & $n$ & $\%^{a}$ & $N$ & $\%^{\mathrm{b}}$ \\
\hline \multicolumn{8}{|l|}{ Age } \\
\hline $18-30$ & & 165 & 23.0 & 552 & 77.0 & 717 & 42.0 \\
\hline $31-40$ & & 341 & 48.1 & 368 & 51.9 & 709 & 41.5 \\
\hline $41-50$ & & 141 & 56.4 & 109 & 43.6 & 250 & 14.6 \\
\hline$\geq 51$ & & 14 & 43.8 & 18 & 56.3 & 32 & 1.9 \\
\hline \multicolumn{8}{|l|}{ Education } \\
\hline primary school & & 64 & 63.4 & 37 & 36.6 & 101 & 5.9 \\
\hline secondary school & & 221 & 42.1 & 303 & 57.8 & 524 & 30.7 \\
\hline university & & 376 & 34.7 & 707 & 65.3 & 1083 & 63.4 \\
\hline \multicolumn{8}{|l|}{ Marital status } \\
\hline single & & 109 & 23.3 & 358 & 76.7 & 467 & 27.3 \\
\hline married & & 552 & 44.5 & 689 & 55.5 & 1241 & 72.7 \\
\hline \multicolumn{8}{|l|}{ Years of work } \\
\hline $1-5$ & & 182 & 28.3 & 461 & 71.7 & 643 & 37.6 \\
\hline $6-10$ & & 113 & 32.8 & 232 & 67.2 & 232 & 20.2 \\
\hline $11-15$ & & 209 & 55.6 & 167 & 44.4 & 376 & 22.0 \\
\hline$\geq 16$ & & 157 & 45.6 & 187 & 54.4 & 344 & 20.1 \\
\hline \multicolumn{8}{|l|}{ Sector } \\
\hline industry & & 57 & 81.4 & 13 & 18.6 & 70 & 4.1 \\
\hline service & & 55 & 34.8 & 103 & 65.2 & 158 & 9.3 \\
\hline security & & 317 & 92.4 & 26 & 7.6 & 343 & 20.1 \\
\hline health & & 201 & 18.8 & 868 & 81.2 & 1069 & 62.6 \\
\hline \multirow[t]{2}{*}{ education } & & 31 & 45.6 & 37 & 54.4 & 68 & 3.9 \\
\hline & total & 661 & 38.7 & 1047 & 61.3 & 1708 & 100 \\
\hline
\end{tabular}

Notes. a-percentage of row, b-percentage of column. 
status work sectors, years of work experience and gender. Most participants worked in the health care sector $(62.6 \%)$, followed by the security sector $(20.1 \%)$. More than one third of participants had worked for 1-5 years, $83.5 \%$ were $18-40$ years of age, whereas $61.3 \%$ were female. Most participants had secondary and university education, $72.7 \%$ were married.

\subsection{Exposure to Workplace Violence}

Exposure to any type of workplace violence in the past year was mentioned by $44.8 \%$ of the respondents. Half of the female participants said that they had been subjected to a type of violent behavior, whereas this ratio was $36.2 \%$ among male participants. Table 2 shows the exposure to workplace violence in the past year. The mostly common type of violence was verbal abuse
(38.5\%), followed by bullying (30.3\%). Among the participants who reported that they had been subjected to any type of violence in the past year, $3.3 \%$ were exposed to physical assault only, $8.9 \%$ to bullying only, $23.8 \%$ to verbal abuse only, $0.5 \%$ to sexual harassment only and $63.9 \%$ to a combination of different types of violence.

Table 3 shows the distribution of respondents according to their work sectors and being subjected to workplace violence or not in the past year. Among the different work sectors, exposure to workplace violence in the past year was mostly reported in the health care sector (51.3\%), followed by the security (38.8\%) and education $(36.8 \%)$ sectors. The difference among the sectors in terms of exposure to workplace violence was statistically significant. Table 4 shows the distribution of participants according to their work sector and exposure to violence categories.

TABLE 2. Exposure to Workplace Violence In the past Year $(N=1708)$

\begin{tabular}{lccccc}
\hline & \multicolumn{2}{c}{ Exposed } & & \multicolumn{2}{c}{ Not Exposed } \\
\cline { 2 - 3 } \cline { 5 - 6 } Type of Violence & $\boldsymbol{n}$ & \% & & $\boldsymbol{n}$ & \% \\
\hline Physical assault & 132 & 7.7 & & 1576 & 92.3 \\
Verbal abuse & 658 & 38.5 & & 1050 & 61.5 \\
Bullying & 518 & 30.3 & & 1190 & 69.7 \\
Sexual harassment & 26 & 1.5 & & 1682 & 98.5 \\
Any type & 765 & 44.8 & & 943 & 55.2 \\
\hline
\end{tabular}

TABLE 3. Exposure to Workplace Violence in Different Work Sectors

\begin{tabular}{lccccc}
\hline & \multicolumn{2}{c}{ Exposed } & & \multicolumn{2}{c}{ Not Exposed } \\
\cline { 2 - 3 } \cline { 5 - 6 } Sector & $\boldsymbol{n}$ & $\%$ & & $\boldsymbol{n}$ & \% \\
\hline Industry $(N=70)$ & 17 & 24.3 & & 53 & 75.7 \\
Service $(N=158)$ & 42 & 26.6 & & 116 & 73.4 \\
Security $(N=343)$ & 133 & 38.8 & & 210 & 61.2 \\
Health $(N=1069)$ & 548 & 51.3 & & 521 & 48.7 \\
Education $(N=68)$ & 25 & 36.8 & & 43 & 63.2 \\
\hline
\end{tabular}

Notes. $\mathrm{X}^{2}=57.984, d f=4, p=.0001$.

TABLE 4. Distribution of Participants According to Type of Violence Exposed to in Different Work Sectors

\begin{tabular}{|c|c|c|c|c|c|c|c|c|}
\hline \multirow[b]{3}{*}{ Sector } & \multicolumn{8}{|c|}{ Type of Violence } \\
\hline & \multicolumn{2}{|c|}{ Physical Assault } & \multicolumn{2}{|c|}{ Verbal Abuse } & \multicolumn{2}{|c|}{ Bullying } & \multicolumn{2}{|c|}{ Sexual Harassment } \\
\hline & $n$ & $\%$ & $n$ & $\%$ & $n$ & $\%$ & $n$ & $\%$ \\
\hline Industry $(N=70)$ & 2 & 2.8 & 16 & 22.8 & 14 & 20.0 & 1 & 1.4 \\
\hline Service $(N=158)$ & 2 & 1.3 & 36 & 22.6 & 27 & 17.1 & 4 & 2.5 \\
\hline Security $(N=343)$ & 71 & 20.7 & 98 & 28.6 & 72 & 20.9 & - & - \\
\hline Health $(N=1069)$ & 55 & 5.1 & 486 & 45.5 & 388 & 36.3 & 20 & 1.8 \\
\hline Education $(N=68)$ & 2 & 2.9 & 22 & 32.4 & 17 & 25.0 & 1 & 1.6 \\
\hline
\end{tabular}


In all of the work sectors, the most common type of violence was verbal abuse, followed by bullying. Physical assault was mostly seen in the security sector, followed by the health care sector, whereas sexual harassment was mostly reported in the service sector, followed by the health care sector.
One hundred and thirty-two participants reported that they had been subjected to physical assault in the past year. Table 5 shows the distribution of the physically violated participants according to the characteristics of the violent behavior, perpetrators and victims.

TABLE 5. Distribution of Violated Participants According to the Characteristics of the Violent Behavior, Perpetrators and Victims

\begin{tabular}{|c|c|c|c|c|c|c|c|c|}
\hline \multirow[b]{3}{*}{ Characteristic } & \multicolumn{8}{|c|}{\begin{tabular}{|c|} 
Type of Violence \\
\end{tabular}} \\
\hline & \multicolumn{2}{|c|}{$\begin{array}{c}\text { Physical Assault } \\
(n=132)\end{array}$} & \multicolumn{2}{|c|}{$\begin{array}{c}\text { Verbal Abuse } \\
(n=658)\end{array}$} & \multicolumn{2}{|c|}{$\begin{array}{l}\text { Bullying } \\
(n=518)\end{array}$} & \multicolumn{2}{|c|}{$\begin{array}{c}\text { Sexual Harassment } \\
(n=26)\end{array}$} \\
\hline & $n$ & $\%$ & $n$ & $\%$ & $n$ & $\%$ & $n$ & $\%$ \\
\hline \multicolumn{9}{|c|}{ Victims } \\
\hline \multicolumn{9}{|l|}{ Age } \\
\hline $18-30$ & 31 & 23.5 & 290 & 44.1 & 230 & 44.4 & 12 & 46.2 \\
\hline $31-40$ & 80 & 60.6 & 270 & 41.0 & 214 & 41.3 & 11 & 42.3 \\
\hline $41-50$ & 18 & 13.6 & 84 & 12.8 & 62 & 12.0 & 1 & 3.8 \\
\hline$\geq 51$ & 3 & 2.3 & 14 & 2.1 & 12 & 2.3 & 2 & 7.7 \\
\hline \multicolumn{9}{|l|}{ Gender } \\
\hline male & 83 & 62.9 & 189 & 28.7 & 142 & 27.4 & 3 & 11.5 \\
\hline female & 49 & 37.1 & 469 & 71.3 & 376 & 72.6 & 23 & 88.5 \\
\hline \multicolumn{9}{|l|}{ Education } \\
\hline primary school & 6 & 4.5 & 15 & 2.3 & 12 & 2.3 & - & - \\
\hline secondary school & 46 & 34.8 & 171 & 26.0 & 135 & 26.1 & 9 & 34.6 \\
\hline university & 80 & 60.6 & 472 & 71.7 & 371 & 71.7 & 17 & 65.4 \\
\hline \multicolumn{9}{|l|}{ Marital status } \\
\hline single & 20 & 15.2 & 184 & 28.0 & 147 & 28.4 & 7 & 27.0 \\
\hline married & 112 & 84.9 & 474 & 72.0 & 371 & 71.6 & 19 & 73.0 \\
\hline \multicolumn{9}{|l|}{ Years of work } \\
\hline $1-5$ & 30 & 22.7 & 237 & 36.0 & 182 & 35.1 & 9 & 34.6 \\
\hline $6-10$ & 19 & 14.4 & 137 & 20.8 & 114 & 22.0 & 7 & 26.9 \\
\hline $11-15$ & 54 & 40.9 & 136 & 20.7 & 104 & 20.1 & 3 & 11.6 \\
\hline$\geq 16$ & 29 & 22.0 & 148 & 22.5 & 118 & 22.8 & 7 & 26.9 \\
\hline \multicolumn{9}{|c|}{ Perpetrators } \\
\hline \multicolumn{9}{|l|}{ Gender } \\
\hline male & 72 & 54.5 & 287 & 43.6 & 195 & 37.6 & 19 & 73.1 \\
\hline female & 14 & 10.6 & 155 & 23.6 & 146 & 28.2 & 3 & 11.5 \\
\hline both & 25 & 18.9 & 146 & 22.2 & 132 & 25.5 & 2 & 7.7 \\
\hline no answer & 21 & 16.0 & 70 & 10.6 & 45 & 8.7 & 2 & 7.7 \\
\hline \multicolumn{9}{|l|}{ Perpetrator } \\
\hline outsider & 71 & 53.8 & 126 & 19.1 & 76 & 14.7 & 8 & 30.8 \\
\hline senior colleague & 13 & 9.8 & 326 & 49.5 & 278 & 53.7 & 7 & 26.9 \\
\hline junior colleague & 4 & 2.4 & 24 & 3.6 & 15 & 2.9 & 3 & 11.5 \\
\hline colleague in same position & 4 & 3.0 & 42 & 6.4 & 42 & 8.1 & 1 & 3.8 \\
\hline combined & 6 & 4.5 & 73 & 11.2 & 67 & 12.9 & 4 & 15.5 \\
\hline no answer & 35 & 26.5 & 67 & 10.2 & 40 & 7.7 & 3 & 11.5 \\
\hline \multicolumn{9}{|c|}{ Violent act } \\
\hline \multicolumn{9}{|l|}{ Frequency } \\
\hline always & 22 & 16.7 & 90 & 13.7 & 102 & 19.7 & 3 & 11.5 \\
\hline sometimes & 67 & 50.7 & 419 & 63.6 & 339 & 65.4 & 12 & 46.2 \\
\hline once or rarely & 37 & 28.0 & 132 & 20.1 & 59 & 11.4 & 10 & 38.5 \\
\hline no answer & 6 & 4.6 & 17 & 2.6 & 18 & 3.5 & 1 & 3.8 \\
\hline
\end{tabular}


When all types of violence are considered, most victims were 18-40, married and university educated. Male victims were subjected to physical assault more than females, whereas more female victims were subjected to verbal abuse, bullying and sexual harassment. For all types of violence, most perpetrators were male. Most perpetrators of physical assault and sexual harassment were persons out of the workplace, whereas the perpetrators of verbal abuse and bullying were mostly senior colleagues. For all types of violence, the violent act occurred mostly sometimes. We performed a binary logistic regression analysis to evaluate if there were relationships among the sociodemographic characteristics and exposure to violent behavior (Table 6).

We did not find a relationship among age, marital status and being exposed to violence at the workplace. However, there was a relationship among gender, educational attainment and years of work experience. Female workers were exposed to workplace violence 1.7 times more than male ones. High-school-educated workers were exposed to violence 2.4 times more and university educated workers 3.5 times more than those with primary school education. As the number of years of work experience increased, exposure to violence increased.

\subsection{Witnessing Workplace Violence}

Nine hundred and fifty-six participants reported that they had witnessed workplace violence in the past year. The most frequently witnessed type of violence was verbal abuse (21.3\%), followed by bullying (17.0\%), physical assault (5.0\%) and sexual harassment $(0.2 \%)$. Ten point two percent of participants reported that they had witnessed different combinations of violence and $2.3 \%$ did not answer.

\subsection{Reactions of Victims}

Table 7 shows the distribution of victims' reactions after the exposure to violence. The victims reported 3310 reactions. The most frequently reported one was talking with colleagues (18.9\%) about the violent act, followed by talking with family and friends (15.7\%) and warning the perpetrator (15.6\%). "Doing nothing" and "pretending nothing had happened" accounted for $15.4 \%$ of the reactions, whereas "getting legal help" and "getting help from the police" accounted for $2.2 \%$. These percentages showed that victims preferred to ignore or deny the violent act had occurred instead of fighting against it.

\subsection{The Impact of Violence}

\subsubsection{Worry about being subjected to a violent act}

Thirty-one point seven percent of participants reported that they would never worry about being subjected to violence, whereas $22.9 \%$ worried rarely. Only $6.8 \%$ reported that they were always worried. Table 8 shows the distribution of participants according to their degree of worry and exposure to workplace violence. The difference between the degrees of worry among

TABLE 6. Logistic Regression Analysis for Exposure to Violence and Sociodemographic Variables (0-not exposed; 1-exposed)

\begin{tabular}{|c|c|c|c|c|c|c|}
\hline \multirow[b]{2}{*}{ Variables } & \multirow[b]{2}{*}{ B } & \multirow[b]{2}{*}{ SE } & \multirow[b]{2}{*}{$p$} & \multirow[b]{2}{*}{$\operatorname{Exp}(B)$} & \multicolumn{2}{|c|}{$95 \% \mathrm{Cl}$ for $\operatorname{Exp}(B)$} \\
\hline & & & & & Lower & Upper \\
\hline Age & -0.022 & 0.012 & .070 & 0.978 & 0.955 & 1.002 \\
\hline Gender $^{\mathrm{a}}$ & 0.530 & 0.109 & .000 & 1.698 & 1.372 & 2.102 \\
\hline Education $^{b}$ & & & .000 & & & \\
\hline secondary & 0.854 & 0.288 & .003 & 2.350 & 1.336 & 4.132 \\
\hline university & 1.244 & 0.280 & .000 & 3.470 & 2.005 & 6.008 \\
\hline Marital status $^{c}$ & 0.176 & 0.129 & .172 & 1.193 & 0.926 & 1.537 \\
\hline Years of work & 0.031 & 0.012 & .012 & 1.032 & 1.007 & 1.057 \\
\hline
\end{tabular}

Notes. Reference categories: a-male; b-primary school; c-married; Cl-confidence interval. Statistically significant results are bolded. 
TABLE 7. Distribution of Victims' Reactions After Exposure to the Violent Act

\begin{tabular}{|c|c|c|c|c|c|c|c|c|c|c|}
\hline \multirow[b]{3}{*}{ Reaction } & \multicolumn{8}{|c|}{ Type of Violence } & & \\
\hline & \multicolumn{2}{|c|}{$\begin{array}{l}\text { Physical } \\
\text { Assault }\end{array}$} & \multicolumn{2}{|c|}{ Verbal Abuse } & \multicolumn{2}{|c|}{ Bullying } & \multicolumn{2}{|c|}{$\begin{array}{c}\text { Sexual } \\
\text { Harassment }\end{array}$} & \multicolumn{2}{|c|}{ Total } \\
\hline & $n$ & $\%$ & $n$ & $\%$ & $n$ & $\%$ & $n$ & $\%$ & $N$ & $\%$ \\
\hline None & 25 & 7.8 & 176 & 11.1 & 139 & 10.5 & 6 & 7.5 & 346 & 10.5 \\
\hline Warning the perpetrator & 48 & 15.0 & 247 & 15.6 & 204 & 15.4 & 16 & 20.0 & 515 & 15.6 \\
\hline $\begin{array}{l}\text { Talking with family and } \\
\text { friends }\end{array}$ & 35 & 11.1 & 251 & 15.8 & 222 & 16.7 & 12 & 15.0 & 520 & 15.7 \\
\hline Talking with colleagues & 51 & 16.0 & 306 & 19.3 & 254 & 19.1 & 16 & 20.0 & 627 & 18.9 \\
\hline Wanting to be transferred & 13 & 4.1 & 54 & 3.4 & 54 & 4.1 & 2 & 2.5 & 123 & 3.7 \\
\hline Getting help from the union & 5 & 1.6 & 30 & 1.9 & 29 & 2.2 & 2 & 2.5 & 66 & 2.0 \\
\hline $\begin{array}{l}\text { Reporting to the } \\
\text { management }\end{array}$ & 25 & 7.8 & 104 & 6.6 & 94 & 7.1 & 5 & 6.3 & 228 & 6.9 \\
\hline Reporting to the manager & 49 & 15.5 & 209 & 13.2 & 168 & 12.6 & 9 & 11.3 & 435 & 13.1 \\
\hline $\begin{array}{l}\text { Pretending nothing had } \\
\text { happened }\end{array}$ & 14 & 4.4 & 82 & 5.3 & 61 & 4.6 & 4 & 5.0 & 161 & 4.9 \\
\hline Reacting with violence & 25 & 7.8 & 57 & 3.6 & 48 & 3.6 & 4 & 5.0 & 134 & 4.0 \\
\hline Getting professional help & 4 & 1.2 & 12 & 0.7 & 12 & 0.9 & 1 & 1.2 & 29 & 0.9 \\
\hline Getting legal help & 14 & 4.4 & 17 & 1.1 & 11 & 0.8 & 0 & 0 & 42 & 1.2 \\
\hline Getting help from the police & 9 & 2.8 & 13 & 0.8 & 9 & 0.7 & 1 & 1.2 & 32 & 1.0 \\
\hline Other & 2 & 0.6 & 25 & 1.6 & 23 & 1.7 & 2 & 2.5 & 52 & 1.6 \\
\hline total & 319 & 100 & 1583 & 100 & 1328 & 100 & 80 & 100 & 3310 & 100 \\
\hline
\end{tabular}

TABLE 8. Degree of Worry About Being Subjected to Violence and Exposure to Violence

\begin{tabular}{|c|c|c|c|c|c|c|c|c|c|c|c|c|}
\hline \multirow[b]{3}{*}{ Violence } & \multicolumn{10}{|c|}{ Worry } & & \\
\hline & \multicolumn{2}{|c|}{ Never } & \multicolumn{2}{|c|}{ Rarely } & \multicolumn{2}{|c|}{ Sometimes } & \multicolumn{2}{|c|}{ Frequently } & \multicolumn{2}{|c|}{ Always } & \multicolumn{2}{|c|}{ Total } \\
\hline & $n$ & $\%$ & $n$ & $\%$ & $n$ & $\%$ & $n$ & $\%$ & $n$ & $\%$ & $N$ & $\%$ \\
\hline Not exposed & 450 & 83.0 & 239 & 61.1 & 152 & 34.1 & 23 & 16.5 & 27 & 23.3 & 891 & 54.5 \\
\hline Exposed & 92 & 17.0 & 152 & 38.9 & 294 & 65.9 & 116 & 83.5 & 89 & 76.7 & 743 & 45.5 \\
\hline total & 542 & 100 & 391 & 100 & 446 & 100 & 139 & 100 & 116 & 100 & $1634^{a}$ & 100 \\
\hline
\end{tabular}

Notes. $\mathrm{X}^{2}=386.158, d f=4, p=.0001 ; \mathrm{a}-74$ participants did not answer.

TABLE 9. Depression, Anxiety and Stress and Exposure to Violence

\begin{tabular}{lccccc}
\hline Violence & Symptom & $\boldsymbol{M}$ & $\boldsymbol{M d n}$ & SD & SE \\
\hline Not exposed & depression & 8.24 & 6 & 7.63 & 0.249 \\
& anxiety & 7.96 & 6 & 6.87 & 0.224 \\
Exposed & stress & 12.55 & 12 & 7.92 & 0.258 \\
& depression & 11.04 & 9 & 8.41 & 0.304 \\
& anxiety & 9.68 & 8 & 7.26 & 0.263 \\
\hline
\end{tabular}

participants who had been exposed to violence and those who had not is significant. Those exposed to violence in the past year were more worried about being subjected to a violent act than those who had not been exposed.

\subsubsection{Depression, anxiety and stress}

Table 9 shows the mean depression, anxiety and stress values of the participants who had been subjected to a violent act in the past year and those who had not. The mean values were 

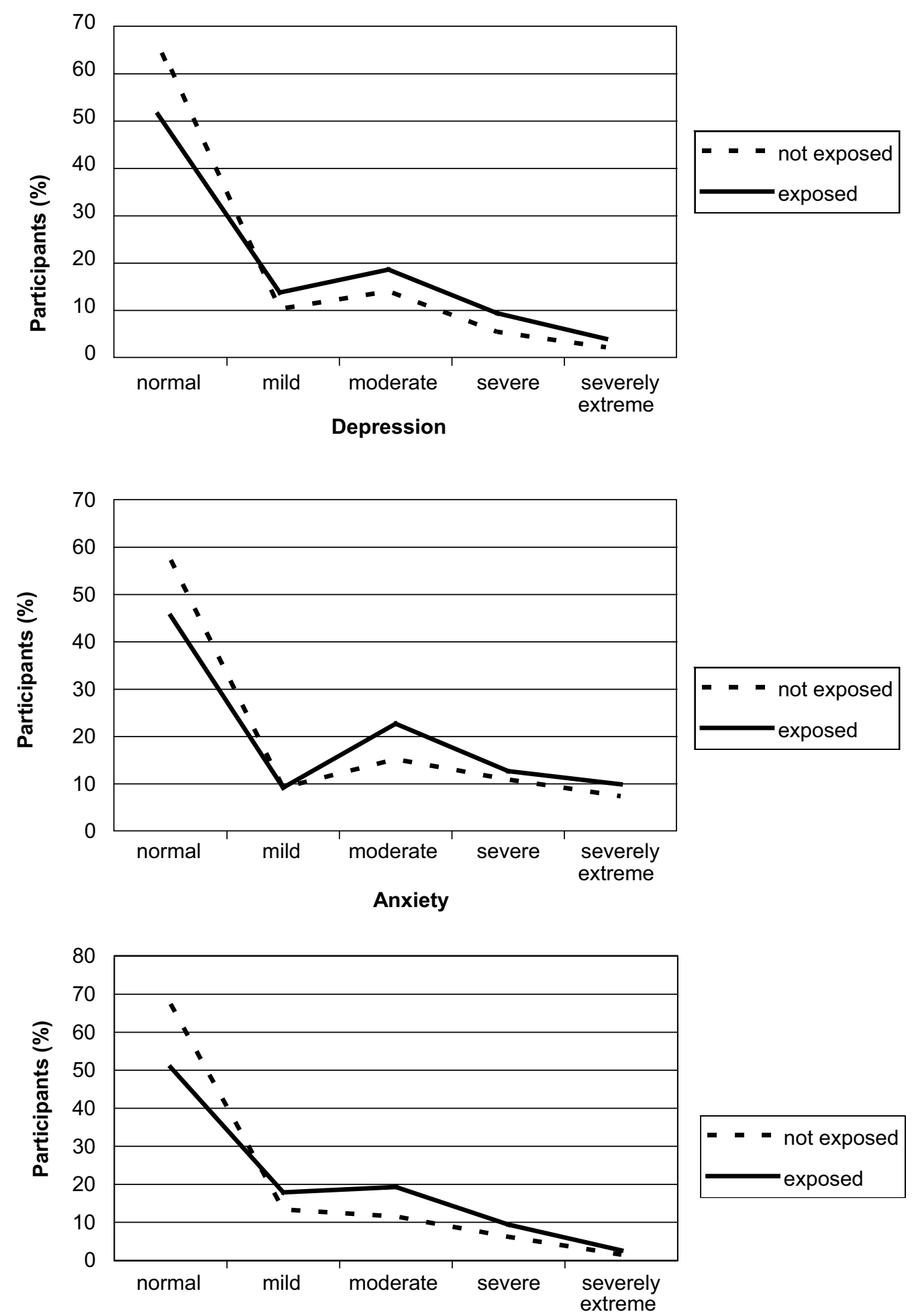

Figure 1. Depression, anxiety and stress levels of participants exposed and not exposed to violence. Notes. Not exposed-did not report exposure to any type of violence, exposed-reported exposure at least one type of violence.

significantly higher among those who reported that they had been subjected to workplace violence than those who reported that they had not (Mann-Whitney $U$ test; $p=.0001$ ). Figure 1 shows the distribution of the participants according to their depression, anxiety and stress levels. 


\subsubsection{Job satisfaction}

The mean value of job satisfaction was 18.3 among participants who did not report any exposure to violence, and 16.8 among participants who had been subjected to violence in the past year. The difference between these two mean values was significant (Mann-Whitney $U$ test; $p=.0001$ ), and participants who had been exposed to workplace violence expressed lower job satisfaction than those who had not been exposed.

\subsubsection{Opinions of the participants about the prevention of workplace violence}

The distribution of the participants regarding their opinions about preventing workplace violence was as follows: implementation of a policy that gives more importance to the issue of workplace violence and to employees (30.8\%); acknowledging to the public and respectfully raising awareness of the act with workers (27.6\%), special training for workers in terms of coping with stress (14.3\%), training to establish better communication skills among workers (14.0\%), organizational support for victims of violence $(6.1 \%)$ and training on workplace violence $(5.4 \%)$.

\section{DISCUSSION}

The present study indicated that many workers had suffered workplace violence over the past year. Nearly half of the workers in our study group reported that they had been subjected to a violent event at their workplaces. Exposure to violence seems to be more prevalent among workers in the health care, security and education sectors. The most common type of violence was verbal abuse (38.5\%), followed by bullying (30.2\%), physical assault (7.7\%) and sexual harassment $(1.5 \%)$. These percentages revealed that psychological (emotional) violence is common among Turkish workers.

In Europe around 1 in 20 (5\%) workers reported having been subjected to bullying and harassment in the workplace in 2005 [29]. However, this low average figure conceals wide variations between countries, ranging from $17 \%$ in Finland and $12 \%$ in The Netherlands to $2 \%$ in Italy and Bulgaria and such differences may reflect different levels of cultural awareness of and sensitivity to the issue as much as differences in actual incidence [29]. Many studies performed in both developed and developing countries showed that workers in the health care sector are at a high risk of being exposed to workplace violence $[1,5,6,7,8,9,11,12,13,14,15,23$, $24,29]$. A study found that health care workers faced 16 times the risk of violence that other workers faced [25]. Most violent acts occurred in hospitals, nursing and personal care facilities and residential care services with most incidents in the form of verbal abuse or bullying [5, $6,7,8,9,11,12,13,14,15,23,24,25]$. Most previous Turkish studies on workplace violence took place in the health care sector and showed a high prevalence of psychological violence [11, $12,13,14,15]$. A study in primary health care settings found that half of the primary health care workers had experienced violence at their workplaces, most frequently verbal abuse [13]. Another study revealed that an overwhelming majority of nurses working in hospitals faced bullying by peers and managers [27]. A recent study among Turkish white-collar workers found that $75 \%$ of nurses and health technicians, $64 \%$ of secretarial and administrative staff, $56 \%$ of police officers, $56 \%$ of physicians and $39 \%$ of teachers had been bullied at their workplaces within the past year [28]. In the present study, verbal abuse and bullying were found to be the most common types of violence reported in the health care sector. In light of previous studies and the present study, it can be said that, in the Turkish health care sector, psychological (emotional) violence is universal and common. On the other hand, in the health care sector and other sectors that we studied, physical assault and sexual harassment were rarely seen. The prevalence of physical assault was highest in the security sector, followed by the health care and education sectors. The low rates of physical assault and sexual harassment may be due to the legal sanctions against these types of violence. Articles 81, 86, 96, 117, 122 and 125 in Turkish 
Criminal Law and articles 24/II, 25/II and 24/II-d in Turkish Labor Law are about physical assault and sexual harassment and mandate sentences for the perpetrators. Unfortunately, there is no legal sanction against psychological (emotional) violence (except insults) in the Turkish juridical system.

Studies across Europe revealed similar results on physical violence and sexual harassment. Physical violence at work affected just a small proportion of the overall workforce (5\%) and higher than average levels were reported in the Netherlands (10\%), France, the UK (9\%) and Ireland (8\%) [29]. The incidence of reported sexual harassment was under $2 \%$ in Europe and female workers in the Czech Republic (10\%), Norway (7\%), Turkey, Croatia (6\%), Denmark, Sweden, Lithuania and the UK $(5 \%)$ were the most affected [29].

In this study, being female, being university educated and having more work experience was found to be significantly associated with becoming a victim of workplace violence. More female than male participants reported that they had been subjected to psychological (verbal abuse and bullying) violence and sexual harassment, whereas for physical assault the opposite was true. A study in Turkish health care settings found no differences between male and female workers in terms of being violated, and verbal abuse as the most frequent form of workplace violence [13]. Another Turkish study among nurses revealed that bullying was a common behavior that nurses faced, and it was more prevalent in public hospitals [27]. In a study conducted among Turkish medical residents, the prevalence of verbal abuse was found to be $67 \%$, and male residents reported more exposure to physical violence than female residents did, whereas sexual harassment was reported more by females [16]. Another study among health care workers in emergency services in Turkey found that females were exposed to workplace violence more than males [11]. The Fourth European Working Conditions Survey found that women were more subjected to bullying and harassment $(6.0 \%)$ than men $(4.0 \%)$ and the risk of experiencing both violence and harassment was greatest in the health and education sectors, followed by public administration and defence sectors [29]. According to a survey of the Central Institute of Labour Protection - National Research Institute (CIOP-PIB) $9.7 \%$ of Polish teachers, who were predominantly women and working at public schools, experienced bullying at work [30].

In this study, university educated participants were found to be more exposed to workplace violence and this finding should be further studied. Some studies showed that white-collar workers were more under the risk of violence than blue-collar ones. In a previous study among university educated Turkish white-collar workers the prevalence of psychological violence was as high as $55.0 \%$ [28]. The Fourth European Working Conditions Survey found that whitecollar workers were somewhat more exposed than blue-collar ones to risks related to violence, harassment and discrimination (6\% compared to 4\%) [29]. High educational attainment was the most important predictor of exposure to violence among primary health care workers in Saudi Arabia [8]. On the other hand a study among U.S. workforce found no differences regarding the workers' educational status [6].

We found that job tenure was significantly associated with exposure to workplace violence and as the number of years of work experience increased, so did exposure to violence. Similar results were obtained from a study among U.S. workforce; there was a positive linear relation for job tenure [6]. Although some studies in the literature revealed an opposite statement, which suggested that new and inexperienced workers were especially vulnerable to violence $[8,13]$. The association between job tenure and exposure to workplace violence should be further studied.

According to our results, most violent acts occurred sometimes. This was true for every type of violence. The perpetrators of physical violence were mostly persons outside the workplace, whereas the perpetrators of psychological violence were mostly senior colleagues. Similar results were found in other studies $[11,12,13$, $14,15,16,26,27,28,29]$. 
The most important finding of this study was the reaction of the victims after the violent act. The most common reaction was talking with family, friends and colleagues about the exposure to violence. Seeking professional or legal advice and getting help from the police were found to be rare reactions. This means that workplace violence in Turkish work settings is still a silent epidemic, and silent epidemics are very dangerous since they cannot be controlled. Similar findings were found in previous studies on violence in Turkish health care settings [11, 12, 13, 14, 15, 16, 27, 28].

According to our findings, most violated workers frequently worried about being exposed to violence at their workplaces compared to those who had not been violated. The health consequences of being exposed to workplace violence are well known $[1,4,5]$. The adverse effects of violence on mental health have been extensively studied. A recent meta-analytic study showed that perceived psychosocial job strain was related to a moderately elevated risk of major depression [31]. Another study revealed that bullying, which was the most commonly reported type of violence in this study, increased the risk of depression 2.3 times [32]. We also found elevated depression anxiety and stress levels among violated workers, and the difference between victimized and nonvictimized workers in terms of depression, anxiety and stress levels was statistically significant. The Fourth European Working Conditions Survey revealed similar results in terms of impact of violence in the workplace and found that the proportion of workers reporting symptoms of psychosocial factors such as sleeping problems, anxiety and irritability was nearly four times greater among those who had experienced violence as among those who had not [29].

In conclusion, workplace violence at the Turkish workplaces we studied is common, especially verbal abuse and bullying. Workers in the health care, security and education sectors are most at risk of workplace violence. Physical assault and sexual harassment are rarely seen and are committed by outsiders, whereas perpetrators of bullying and verbal abuse are senior colleagues. In the light of this study we can say that interventions for preventing violence in Turkish workplaces are essential. These preventive measures should take the most prevalent type of violence namely psychological violence into consideration. Cues for the intervention programs could be summarized as follows:

- First of all, the problem should be identified and reported.

- Organizational climate which encourages violence, especially psychological violence, should be changed.

- Preventive measures, which include a wide range of interventions from education to social support for the victims, should be undertaken.

- Special needs for effective interventions should be determined for every workplace separately according to the type of work and working conditions.

Workplace violence in Turkish workplaces is a silent epidemic, with neither preventive measures nor social support. These findings revealed an urgent need for action in the workplace against all types of workplace violence and the adaptation of zero tolerance policies.

\section{Study Limitations}

The cross-sectional nature of this study is a limitation because we were not able to make causal relationships. Another limitation is the self-report, which may cause recall bias and under-reporting. Furthermore, the findings of this study cannot be generalized and are limited to the workplaces that participated in the study. Although we tried to obtain a study group according to the actual proportional distribution of workers in different working sectors, the respond rate was not equal among the sectors. For example, the highest response rate came from the health sector $(88.9 \%)$, whereas the lowest from the education sector (47.4\%). Therefore most participants in our study group were those from the health sector. The gender differences among the participants from the health and security sectors are a result of actual 
gender differences in these two sectors. However, despite the study's limitations, this study gives valuable information about workplace violence in a developing country and, to our knowledge, may be the first study about workplace violence performed in Turkey that took different work sectors into account.

\section{REFERENCES}

1. Krug EG, Dahlberg LL, Mercy JA, Zwi AB, Lozano R. World report on violence and health. Geneva, Switzerland: WHO; 2002. Retrieved May 24, 2011, from: http://whqlibdoc.who.int/hq/2002/92 41545615.pdf

2. Mayhew C. Occupational violence in industrialized countries: types, incidence patterns and at risk groups of workers. In: Gill M, Fisher B, Bowie V, editors. Violence at work: causes, patterns and prevention. Cullompton, Devon, UK: Willan; 2001. p. 21-40.

3. Spector P, Fox S, Domagalski T. Emotions, violence and counterproductive work behavior. In: Kelloway $\mathrm{K}$, Barling J, Hurrell JJ, editors. Handbook of workplace violence. Thousand Oaks, CA, USA: Sage; 2006. p. 29-46.

4. Glomb TM, Cortina LM. The experience of victims: using theories of traumatic and chronic stress to understand individual outcomes of workplace abuse. In: Kelloway K, Barling J, Hurrell JJ, editors. Handbook of workplace violence. Thousand Oaks, CA, USA: Sage; 2006. p. 517-34.

5. Di Martino V. Workplace violence in the health sector. Country case studies. Brazil, Bulgaria, Lebanon, Portugal, South Africa, Thailand and an additional Australian study. Synthesis report. 2002. Retrieved May 24, 2011, from: http://www.who. int/violence_injury_prevention/injury/en/ WVsynthesisreport.pdf

6. Schat ACH, Frone MR, Kelloway EK. Prevalence of workplace aggression in the U.S. workforce: findings from a national study. In: Kelloway K, Barling J, Hurrell JJ, editors. Handbook of workplace violence.
Thousand Oaks, CA, USA: Sage; 2006. p. 47-89.

7. Gascón S, Martinez-Jarreta B, GonzalezAndrade JF, Santed MA, Casalod Y, Rueda MA. Aggression towards health care workers in Spain: a multi-facility study to evaluate the distribution of a growing violence among professionals, health facilities and departments. Int $\mathbf{J}$ Occup Environ Health. 2009;15:30-6.

8. El-Gilany AH, EL-Wehady A, Amr M. Violence against primary health care workers in Al-Hassa, Saudi Arabia. J Interpers Violence. 2010;25(4):716-34 (DOI:10.1177 /0886260509334395).

9. Hesketh KL, Duncan SM, Estrabrooks CA. Workplace violence in Alberta and British Columbia hospitals. Health Policy. 2003; 63:311-21.

10. Grenyer BFS, Ilkiw-Lavalle O, Biro P. Safer at work: development and evaluation of an aggression and violence minimization program. Aust NZ J Psychiat. 2004;38: 1440-614.

11. Canbaz S, Dündar C, Dabak S, Sunter AT, Peksen Y, Cetinoglu EC. Violence towards workers in hospital emergency medical care units in Samsun: an epidemiological study. Ulus Travma Acil Cerrahi Derg. 2008;14:239-44.

12. Ayranci U. Violence toward health care workers in emergency departments in West Turkey. J Emerg Med. 2005;28:361-5.

13. Ayranci U, Yenilmez C, Balci Y, Kaptanoglu C. Identification of violence in Turkish health care settings. J Interpers Violence. 2006;21:276-96.

14. Senuzun-Ergun F, Karadakovan A. Violence towards nursing staff in emergency departments in one Turkish city. Int Nurs Rev. 2005;52:154-60.

15. Kisa S. Turkish nurses' experiences of verbal abuse at work. Arch Psychiat Nurs. 2008;22:200-7.

16. Acik Y, Deveci E, Gunes G, Gulbayrak C, Dabak S, Saka G, et al. Experience of workplace violence during medical speciality training in Turkey. Occup Med (London). 2008;58:361-6. Retrieved May 24, 2011, from: http://occmed.oxfordjournals.org/conte nt/58/5/361.full .pdf + html 
17. International Labor Office ILO, International Council of Nurses ICN, World Health Organization WHO, Public Services International PSI. Workplace violence in the health sector. Country case studies research instruments, survey questionnaire. Geneva, Switzerland: ILO/ICN/WHO/PSI; 2003. Retrieved May 24, 2011, from: http:// www.who.int/violence_injury_prevention/ violence/interpersonal/en/WVquestionnaire .pdf

18. International Labor Office ILO, International Council of Nurses ICN, World Health Organization WHO, Public Services International PSI. Workplace violence in the health sector. Framework guidelines for addressing workplace violence in the health sector. Geneva, Switzerland: ILO/ICN/WHO/ PSI; 2002. Retrieved May 24, 2011, from: http://www.icn.ch/images/stories/documents/ pillars/sew/sew_framework_guidelines_for_ addressing_workplace_violence.pdf

19. Brayfield AH, Rothe HF. An index of job satisfaction. J Appl Psychol. 1951;35:307-11.

20. Bilgin, N. Sosyal psikolojide yontem ve pratik calismalar [Methods and practical applications in social psychology]. Istanbul, Turkey: Sistem Yayincilik; 1995.

21. Psychology Foundation of Australia. Depression anxiety and stress scales (DASS). Retrieved May 24, 2011, from: http://www2.psy.unsw.edu.au/groups/dass//

22. Uncu Y, Bayram N, Bilgel N. Job related affective well-being among primary health care physicians. Eur J Public Health. 2006; 17:514-9.

23. Ng K, Yeung J, Cheung I, Chung A, White P. Workplace violence-a survey of diagnostic radiographers working in public hospitals in Hong Kong. J Occup Health. 2009;51:355-63.
24. Boyle M, Koritsas S, Coles J, Stanley J. A pilot study of workplace violence towards paramedics. Emerg Med J. 2007;24:760-3.

25. Elliott P. Violence in health care: what nurse managers need to know. Nurs Manage. 1997;28:38-41.

26. Quine L. Workplace bullying in NHS community trust staff questionnaire survey. BMJ. 1999;318:228-32.

27. Yildirim A, Yildirim D. Mobbing in the workplace by peers and managers: mobbing experienced by nurses working in healthcare facilities in Turkey and its effects on nurses. J Clin Nurs. 2007;16: 1444-53.

28. Bilgel N, Aytac S, Bayram N. Bullying in Turkish white-collar workers. Occup Med (London). 2006;56:226-31.

29. Parent-Thirion A, Macias EF, Hurley J, Vermeylen G. Violence, harassment and discrimination in the workplace. In: Fourth European Working Conditions Survey (chapter 4). Dublin, Ireland: European Foundation for the Improvement of Living and Working Conditions: 2007. p. 35-40. Retrieved May 24, 2011, from: http://www. eurofound.europa.eu/pubdocs/2006/98/ en/2/ef0698en.pdf

30. European Working Conditions Observatory. One in 10 teachers subject to mobbing at work. Retrieved February 18, 2010, from: http://www.eurofound.europa.eu/ewco/ 2009/10/PL0910019I.htm

31. Bonde JPE. Psychosocial factors at work and risk of depression: a systematic review of the epidemiological evidence. Occup Environ Med. 2008;65:438-45.

32. Kivimaki M, Virtanen M, Vartia M, Elovainio M, Vahtera J, KeltikangasJärvinen L. Workplace bullying and the risk of cardiovascular disease and depression. Occup Environ Med. 2003; 60:779-83. 


\section{Examples of Questionnaire Items}

The first part of the questionnaire was about sociodemographic characteristics, working status of the participants and about their workplace.

The second part of the questionnaire was about workplace violence and consisted of the following questions.

13. Were you physically assaulted in the past 12 months at your workplace? (Physical assault refers to the use of physical force against another person or group that results in physical, sexual or psychological harm. Physical assault can include beating, kicking, slapping, stabbing, shooting, pushing, biting and/or pinching, among others.)
1. Yes (Go to \#14)
2. No (Go to \#15)
3. Don't know (Go to \#15)

14. If you answered YES in \#14, please indicate the frequency of the assault, the position and the gender of the perpetrator by ticking the appropriate box below.

\begin{tabular}{|l|l|l|l|}
\hline & $\begin{array}{c}\text { A. FREQUENCY OF } \\
\text { PHYSICAL ASSAULT }\end{array}$ & $\begin{array}{c}\text { B. POSITION OF } \\
\text { PERPETRATOR }\end{array}$ & $\begin{array}{c}\text { C. GENDER OF } \\
\text { PERPETRATOR }\end{array}$ \\
\hline A.1. Always & & & \\
\hline A.2. Sometimes & & & \\
\hline A.3. Once & & & \\
\hline $\begin{array}{l}\text { B.1. Out of the } \\
\text { workplace }\end{array}$ & & & \\
\hline B.2. Senior colleague & & & \\
\hline B.3. Junior colleague & & & \\
\hline $\begin{array}{l}\text { B.4. Colleague in } \\
\text { same position }\end{array}$ & & & \\
\hline C.1. Male & & & \\
\hline C.2. Female & & & \\
\hline
\end{tabular}

15. Were you been bullied in the past 12 months at your workplace? (Bullying refers to offensive behavior repeated over time through vindictive, cruel or malicious attempts to humiliate or undermine an individual or groups of employees.)

1. Yes (Go to \#16)

2. No (Go to \#17)

3. Don't know (Go to \#17)

16. If you answered YES in \#15, please indicate the frequency of bullying, the position and the gender of the perpetrator by ticking the appropriate box below.

\begin{tabular}{|l|l|l|l|}
\hline & $\begin{array}{c}\text { A.FREQUENCY OF } \\
\text { BULLYING }\end{array}$ & $\begin{array}{c}\text { B. POSITION OF } \\
\text { PERPETRATOR }\end{array}$ & $\begin{array}{c}\text { C. GENDER OF } \\
\text { PERPETRATOR }\end{array}$ \\
\hline A.1. Always & & & \\
\hline A.2. Sometimes & & & \\
\hline A.3. Once & & & \\
\hline $\begin{array}{l}\text { B.1. Out of the } \\
\text { workplace }\end{array}$ & & & \\
\hline B.2. Senior colleague & & & \\
\hline $\begin{array}{l}\text { B.3. Junior colleague } \\
\text { B.4. Colleague in same } \\
\text { position }\end{array}$ & & & \\
\hline C.1. Male & & & \\
\hline C.2. Female & & & \\
\hline
\end{tabular}


17. Were you verbally abused in the past 12 months at your workplace? (Verbal abuse refers to the use of words that were personally insulting, such as generally abusive spoken obscenities and foul language, or indicating a lack of respect for the dignity and worth of an individual.)

1. Yes (Go to \#18)

2. No (Go to \#19)

3. Don't know (Go to \#19)

18. If you answered YES in \#17, please indicate the frequency of verbal abuse, the position of the perpetrator and the gender of the perpetrator by ticking the appropriate box below.

\begin{tabular}{|l|l|l|l|}
\hline & $\begin{array}{c}\text { A. FREQUENCY OF } \\
\text { VERBAL ABUSE }\end{array}$ & $\begin{array}{c}\text { B. POSITION OF } \\
\text { PERPETRATOR }\end{array}$ & $\begin{array}{c}\text { C. GENDER OF } \\
\text { PERPETRATOR }\end{array}$ \\
\hline A.1. Always & & & \\
\hline A.2. Sometimes & & & \\
\hline A.3. Once & & & \\
\hline $\begin{array}{l}\text { B.1. Out of the } \\
\text { workplace }\end{array}$ & & & \\
\hline B.2. Senior colleague & & & \\
\hline $\begin{array}{l}\text { B.3. Junior colleague } \\
\text { B.4. Colleague in } \\
\text { same position }\end{array}$ & & & \\
\hline C.1. Male & & & \\
\hline C.2. Female & & & \\
\hline
\end{tabular}

19. Were you sexually harassed in the past 12 months at your workplace? (Sexual harassment refers to any unwanted, unreciprocated and unwelcome behavior of a sexual nature that is offensive to the person involved, and causes that person to feel threatened, humiliated or embarrassed.)

1. Yes (Go to \#20)

2. No (Go to \#21)

3. Don't know (Go to \#21)

20. If you answered YES in \#19, please indicate the frequency of verbal abuse, the position of the perpetrator and the gender of the perpetrator by ticking the appropriate box below.

\begin{tabular}{|l|l|l|l|}
\hline & $\begin{array}{c}\text { A. FREQUENCY OF } \\
\text { SEXUAL HARASSMENT }\end{array}$ & $\begin{array}{c}\text { B. POSITION OF } \\
\text { PERPETRATOR }\end{array}$ & $\begin{array}{c}\text { C. GENDER OF } \\
\text { PERPETRATOR }\end{array}$ \\
\hline A.1. Always & & & \\
\hline A.2. Sometimes & & & \\
\hline A.3. Once & & & \\
\hline $\begin{array}{l}\text { B.1. Out of the } \\
\text { workplace }\end{array}$ & & & \\
\hline B.2. Senior colleague & & & \\
\hline B.3. Junior colleague & & & \\
\hline $\begin{array}{l}\text { B.4. Colleague in } \\
\text { same position }\end{array}$ & & & \\
\hline C.1. Male & & & \\
\hline C.2. Female & & & \\
\hline
\end{tabular}


21. Please answer this question if you were physically assaulted, bullied, verbally abused or exposed to sexual harassment in the past 12 months at your workplace. If you were not been exposed to any of the behaviors above, please leave it blank. How did the violent event affect you?

\begin{tabular}{|l|l|l|l|l|l|}
\hline & Never & Rarely & Sometimes & Frequently & Always \\
\hline $\begin{array}{l}\text { 1. I thought about the event } \\
\text { and it bothered me }\end{array}$ & & & & & \\
\hline 2. I avoided thinking about it & & & & & \\
\hline $\begin{array}{c}\text { 3. I had to be always awake } \\
\text { and alert }\end{array}$ & & & & & \\
\hline $\begin{array}{l}\text { 4. I felt that everything was } \\
\text { a struggle }\end{array}$ & & & & & \\
\hline
\end{tabular}

22. Have you ever witnessed any type of violence at your workplace?

1. Yes, physical assault

2. Yes, bullying

3. Yes, verbal abuse

4. Yes, sexual harassment

5. No

23. Please indicate the degree of your worry about being exposed to any type of violence at your workplace.
1. Never
2. Rarely
3. Sometimes
4. Frequently
5. Always

24. How did you respond to the violent act that you faced ? (If you have not exposed to any type of violence, please leave it blank). You can tick more than one box.

\begin{tabular}{|l|l|l|l|l|}
\hline 1. I did nothing & $\begin{array}{c}\text { Physical } \\
\text { assault }\end{array}$ & $\begin{array}{c}\text { Verbal } \\
\text { abuse }\end{array}$ & Bullying & $\begin{array}{c}\text { Sexual } \\
\text { harassment }\end{array}$ \\
\hline $\begin{array}{l}\text { 2. I warned the perpetrator and told him/her to stop violent } \\
\text { behavior }\end{array}$ & & & & \\
\hline 3. I talked about it with my family/friends & & & & \\
\hline 4. I talked about it with my colleagues & & & & \\
\hline 5. I wanted to be transferred to another place & & & & \\
\hline 6. I asked my union for help & & & & \\
\hline 7. I reported the violent act to the management & & & & \\
\hline 8. I reported the violent act to my manager & & & & \\
\hline 9. I pretended nothing had happened & & & & \\
\hline 10. I reacted with violence and defended myself & & & & \\
\hline 11. I got professional help & & & & \\
\hline 12. I got legal help & & & & \\
\hline 13. I got help from police & & & & \\
\hline 14. Other (specify) & & & & \\
\hline
\end{tabular}


26. What do you think your manager/management should do to prevent workplace violence?

1. Implementation of a policy that gives more importance to the employees and the issue of workplace violence

2. Training to establish better communication skills among workers

3. Training and education of workers regarding workplace violence

4. Special training for workers in terms of coping with stress

5. Organizational support for the victims of violence

6. Acknowledging to the public and raising awareness of the act with workers

7. Other (please specify):

The third part of the questionnaire was arranged to measure job satisfaction and depression, anxiety and stress levels of the participants. For this purpose we used two scales: the Job Satisfaction Scale [19, 20] and DASS-42 (Depression-Anxiety-Stress-Scale-42) [21, 22]. 